\title{
Trichorhinophalangeal Syndrome Type I
}

National Cancer Institute

\section{Source}

National Cancer Institute. Trichorhinophalangeal Syndrome Type I. NCI Thesaurus. Code C75109.

A rare autosomal dominant syndrome caused by mutations in the TRPS1 gene. It is characterized by distinctive facial appearance (sparse hair, pear-shaped nose, and elong ated philtrum), skeletal abnormalities (cone-shaped epiphyses, hip malformation), short stature, and mild growth retardation. 